\title{
Self-Transformation through Love in \\ Elif Shafak's The Forty Rules of Love with Relevance to \\ the Character of Desert Rose the Harlot
}

\section{Rania Mohamed Abdel Mageed}

\begin{abstract}
As a fundamental part of the human experience, Love has always had an immense impact and importance in the world literature. There is perhaps no other theme in literature as prevailing, challenging, and diverse as that of love. Writers and critics through ages have tried to examine the complex theme of love and explore the different kinds and consequences of love in their literary works. One of the writers who have been preoccupied by the theme of love in their writings is the eminent Turkish novelist, Elif Shafak. Her perception of love is of great prominence to this research. In her novel The Forty Rules of Love (2009), Shafak depicts love with its divine and human dimensions and establishes it as the very essence and purpose of life. From the radical criticisms of the role that love has played in maintaining patriarchal relations to the more foundational thinking about love as a positive and productive force, love has furthermore particularly played an important role in feminist literary theory and criticism throughout its history. This research paper uses the recent Feminist Love Studies as its framework to scrutinize and establish love, found in places unexpected and brusquely, as the only path for self-transformation through the analysis of the character of Desert Rose the Harlot in Elif Shafak's The Forty Rules of Love.
\end{abstract}

Keywords: love, self-transformation, feminist theory, feminist love studies, selfexpression, women, power, society 


\section{Introduction}

A life without love is of no account. Don't ask yourself what kind of love you should seek ... Love has no labels, no definitions. It is what it is, pure and simple. Love is the water of life. And a lover is a soul of fire. The universe turns differently when fire loves water. (Shafak 2009, p. 40)

Love is one of the most intriguing, spellbinding, and captivating topics which seem to be continuously discussed in literature. It is a complex and multifaceted concept that encompasses a variety of feelings, states, and attitudes with both positive and negative attributes. Love can either endorse human kindness, compassion, benevolence, commitment and/or affection, or flame human moral flaws such as vanity, selfishness, greed, obstinacy, arrogance and egotism. This diversity and complexity make love unusually difficult to consistently define it compared to other emotional states.

Nevertheless, writers and critics throughout the history of literary canon have acknowledged and identified seven types of love, that are loosely based on classical readings of Plato and Aristotle and on JA Lee's 1973 book, Colors of Love. These types are: Eros, the sexual or passionate love that is a form of madness brought about by one of Cupid's arrows. It is commonly contrasted with Logos, or Reason, with Cupid painted as a blindfolded child; Philia, platonic love that bears goodwill to another person for one of three reasons: being useful; pleasant; or good, that is, rational and virtuous; Storge, familial love that is a kind of philia pertaining to the love between parents and their children; Agape, is universal love, such as the love for strangers, nature, or God. It encompasses the modern concept of altruism; Ludus, is playful or uncommitted love involving flirting, seducing, and conjugating; Pragma, is a kind of practical love founded on reason or duty and one's longer-term interests; and Philautia, is self-love, which can be healthy or unhealthy. Unhealthy selflove awakens an inflated sense of one's status, abilities, or accomplishments, along with haughtiness or arrogance promoting injustice, conflict, and enmity. Healthy self-love, on the other hand, relates to self-esteem. It is the cognitive and emotional appraisal of one's own worth.

Love has been therefore one of the most dominant, provocative, diverse and enchanting themes in the novel as a distinctive genre of literature that describes intimate human experiences. With a continuous and comprehensive history of about two thousand years- with its origins in the Ancient Greek and Roman novel, in Chivalric romance, and in the tradition of the Italian renaissance novella- novels have abundantly depicted love as a key complex component of what the writers have tried to express and illuminate for their readers. No matter which kind of love a character experiences, it ultimately brings him or her closer to, or makes them more a part of, the ultimate theme of universal love.

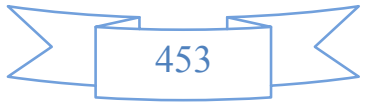


Elif Shafak's The Forty Rules of Love (2009) is one of the novels that speak volumes about love. The novel is both enchanting and enlightening. It is a bookin-a-book where a forty-year-old housewife in Boston, Ella, is reading a manuscript from a new author from Turkey as part of her job working for a literary agent. The title of the book is Sweet Blasphemy and it is written by a travelling photographer named Aziz. Through the tale, Ella, together with the reader, is taken back to the thirteen century Anatolia, to the adventures of a wandering dervish called Shams, who is travelling to a distant city to meet with his soul mate, Rumi, a respected scholar and preacher, whom he has met in his vision. While the actual book is written in the third person, Sweet Blasphemy is written in a first person account with each chapter bearing the name of the person who is narrating her/his experience encountering Shams. On his journey, Shams meets the outcasts of society and help them regain their lost spirit and pride by teaching them about the 'Forty Rules of Love'. The personal story of Desert Rose the Harlot, in particular, however, is central to the depiction of the theme of love in the novel. Desert Rose the Harlot, the broken, brutalized prostitute, passes through a reflective transformation when she meets Shams after being spotted in the mosque listening to Rumi preach. With the help of Shams and through love, Desert Rose the Harlot changes radically to a profound courageous woman who retains her humanity and leaves everything from her old life behind her.

Since the beginning of the twenty-first century, and in contrast to previous reluctance in most disciplines to take love seriously as a subject of academic research, fast growing attention to the topic of love has developed in literary studies. This growing attention is manifested in many different disciplines and interdisciplinary work, among both feminist and non-feminist scholars. In literary criticism, Love is increasingly being taken as a serious area of study on its own terms, rather than just in relation to connected concepts such as "care", "labor", " romance", " trust" and/or "sexual desire". (Jónasdóttir 2014, p.2)

The field of Love Studies has subsequently been expanding since the early 1990 s as a new field of academic scholar. It is also significant that love within this new field of study is being considered as an important ethical, social, and/or political force. Furthermore, a distinctive Feminist Love Studies has emerged since 2013 and has contributed eminently to broadening and deepening Love Studies. It calls the feminist community's attention to the growing area of love studies and the significance of its focus on the positive and productive aspects of love. The transformational nature of love in particular has been articulated; because love has the capacity to change people and societies.

This research paper uses the flourishingly expanding Feminist Love Studies as its framework to scrutinize and establish love as the only path for selftransformation through the analysis of the character of Desert Rose the Harlot in Elif Shafak's The Forty Rules of Love.

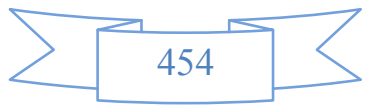




\section{Discussion}

The quest for Love changes us. There is no seeker among those who search for Love who has not matured on the way. The moment you start looking for Love, you start to change within and without. (Shafak 2009, p. 87)

Throughout history, Love has played a significant role in feminist ideology, from the early thoughts of Mary Wollstonecraft and Simone de Beauvoir to the work of a wide range of philosophers and thinkers since then. These thoughts and philosophies include the important radical criticisms of the role that love has played in maintaining patriarchal relations, such as those of Ti-Grace Atkinson, and Catherine MacKinnon; of Marxist feminists Nancy Hartsock and Silvia Federici; and of psychoanalytic feminists Nancy Chodorow and Juliet Mitchell. Since the late 1970s and through the 1980s, an increasing number of feminists, particularly those influenced by psychoanalysis, have produced foundational fundamental thoughts about love as a productive force in feminist theory. These include Julia Kristeva, Hélène Cixous, and Audre Lorde. Prominent Feminist philosophers have later on provided the basis for current productive understandings of love and contributed to Feminist Love Studies in a broader sense. These include Alison Jaggar (Love and Knowledge) (Jaggar 1989), Sandra Bartky (Emotional Labor) (Bartky 1990), and Ann Ferguson (Sex/affective energy and Sex/affective production) (Ferguson 1991).

In the introduction to Love: A Question for Feminism in the Twenty-First Century, co-editors Ferguson and Jónasdóttir establish the field of "Love Studies" as a " new, expanding field of academic scholarship" (Jónasdóttir and Ferguson 2014, p.1) that has been growing since the 1990s across many disciplines and fields. Earlier than that, however, there have been an increasing numbers of feminist theorists and philosophers who have been taking love as a serious area of study. This feminist philosophical focus on love has further grown widely since then. This is evidently manifested through the sheer number of books and journal articles that have been recently published related to the field of "Love Studies", which hold considerations of rethinking the notion of love. Hypatia, the renowned academic Journal of Feminist Philosophy that is published quarterly by Cambridge University Press, for instance has been publishing steady loads of articles on issues relating to Love Studies since 2002.

While traditional philosophical inquiries into separate areas of ontology, epistemology, ethics, aesthetics and politics, feminist thought examines these separate areas as inevitably linked. Most feminist philosophers touch on two or more in some cases, all of them. It would be of course irrelevant to the scope of this research paper to examine all of these themes. For the purpose of this research paper, ontological questions are investigated to help provide an insight on the different ways of thinking and securitize the philosophical approach of the Feminist Love Studies to the notion of love as bound to creativity and /or as

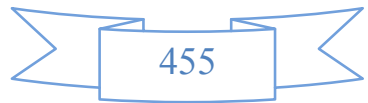


a productive power of some specific kind capable of enacting major transformation.

Traditional philosophical inquires into ontological questions, the most basic being "what is love?," include inquiries such as whether love is a property of the mind or the body, whether bodily love is connected with spiritual love, and if divine love is the same as human love. Feminist love studies, on the other hand, address many of these ontological issues differently. For example, the traditional Greek divisions of eros, agape, philia, and storge are sometimes widened to include new kinds of love, and sometimes this rethinking radically changes not just the thought of what love is, but the people and their worlds as well.

Similarly, many feminist philosophers rethink what love is by 'deconstructing binary' oppositions implied in traditional philosophies of love. It is, therefore, argued that feminist thinkers provide ways of considering love in all of its forms as natural, although not perfect. For instance, feminist philosophers break down traditional oppositions between sexual love and spiritual or sacred love. In a feminist reinterpretation of Augustine on sexual desire versus sacred love, feminist thought suggests that Augustine's texts, and his relationships with women, provide at once a gendered understanding of love as bodily, but also a rethinking of its non-gendered aspects. In the feminist revisionist reading, Augustine does not set up a theological division between a divine and perfect intellectual love and a worldly and depraved bodily desire. Augustine, it is argued, views the body as beautiful, God-made, and as naturally lovable. The distinction between spiritual and bodily joy is thus refused by feminist philosophers. It is rather argued that sexual love might take on supernatural powers, and might be elevated to spiritual heights which give love its transformative powers.

This transformational nature of love is central to Feminist Love Studies and the scope of research in this paper. Feminist philosophers believe that love has the capacity to change people and societies while being constantly changing. The concept of love as transformation assumes that people are transformed through their interactions in the experience of love. Feminist thought has thus focused on the importance of rethinking love as a transformative force in the face of social practices and/or hypocrisies. From this point of view, 'love power' can be seen as a potential force and/or energy for transformation and empowering practices. In Elif Shafak's The Forty Rules of Love, the Character of Desert Rose the Harlot presumes the power for self-transformation, once she encounters love.

Elif Shafak (born 1971) is a Turkish-British writer and women's rights activist. Shafak's novel The Forty Rules of Love focuses on love in the light of Rumi, Mewlānā Jalāl ad-Dīn Muhammad Balkhi, the Sunni Muslim, jurist, theologian, scholar and the great poet, and Shams of Tabriz, the Persian poet who is credited as the spiritual instructor of Rumi. In her "Why The Novel Matters in the Age of Anger," Shafak confirms that it is the duty of the novelist to pose simple yet

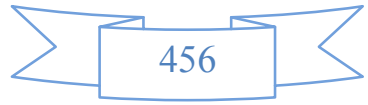


difficult questions for the readers to crave out their meanings; and "to rehumanize those who have been dehumanized". To her a novel is "a free, egalitarian space where a diversity of voices can be heard, nuances celebrated, and the unsayable can be said" (p.6-7)

The Forty Rules of Love is a novel that tells two parallel stories that mirror each other across two very different cultures and seven intervening centuries. It starts when a housewife, Ella, gets a book called Sweet Blasphemy for an appraisal. This book is about the thirteenth century poet, Rumi and his spiritual teacher, Shams. The story presented in Forty Rules of Love is basically on 'love' to explore what it means to follow one's heart. Elif Shafak's notion of love therefore stands out prominently in the novel. She emphasizes in an interview to Nazli Demiroz, "I wanted to discuss 'love' with its divine and human dimensions. West and East, past and present."(p.5) The novel thus intrigues the reader "to contemplate the silences and sufferings of the souls of the characters who represent the society with its diversity," from the famous preacher to the infamous prostitute. (p.5) In the process, it is noted that it is in the cohesive power of love that each and every character find the right way through their predicaments. In Elif Shafak's The Forty Rules of Love, the notion of love is examined as the only power for self-transformation through the analysis of the character of Desert Rose the Harlot, the prostitute.

Desert Rose the Harlot is one of the most intriguing characters in the novel. Her beauty is fascinating and her courage, bravery and transformation through the 'power of love' are amazingly extraordinary. People look down upon her since she is a 'prostitute'. When first seen in the novel Desert Rose the Harlot says:

There is something that amazes me: why is it that although people say they hate seeing women prostitutes themselves, the same people make life hard for a prostitute who wants to repent and start life? It is as if they are telling us they are sorry that we have fallen so low, but now that we are where we are, we should stay there forever. I don't know why this is. All I know is, some people feed on the miseries of others and they don't like it when there is one less miserable person on the face of earth. But no matter what they say or do, I am going to walk out of this place one day. (Shafak 2009, p.171)

As a little girl, Desert Rose represents innocent youth being destroyed by the evils in the world and only rescued through the power of love, God's love. She was born in Constantinople under troubling times where tales of the Crusaders, the Seljuks, and the Mongols were spreading in all cities and the countryside and no one was safe; "You were born in the right place, but I am afraid it was under the wrong star" says her mother, "The times were bad, unpredictable." Born to a Christian family, the little girl always felt close to God, "Every night before going to sleep, I thanked the Lord for not sending me to bed hungry. It felt like talking to a friend," Rose says. But everything changed once her mother

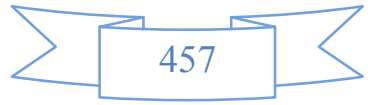


died; "With my mother gone and my father turned into a sullen, bitter man, life was never the same," Desert Rose asserts. (pp.172-175)

Her heartbroken father shortly followed her mother, he was "found dead, killed with rat poison" and the little girl was left alone in the world at the age of thirteen in Constantinople to stay with a distant aunt. A gang of robbers kidnapped her, however, and took her to a village deep in a neighboring forest. She was forced to lay with the chief of the village. The memory of such time was unspeakable to her. She thus describes it:

The chief of the village was severely ill with nervous fever. He had been in bed for a long time, with red spots all over his body, trying countless treatments to no avail. Recently someone had convinced him that if he slept with a virgin, his illness would be transmitted to her and he would be clean and cured. There are things in my life I don't want to remember. (p.176)

Little did Desert Rose know that once she reached the city of Constantinople things would be even more brutal: "The city was worse. It was ruthless." Women like her, with no family, capital and support had little chance of surviving: "It didn't take the city long to crush my spirits and ruin my body. Suddenly I was in another world altogether - a world of malice, rape, brutality, and disease. I saw things on those streets for which I have no words". (p.177)

Desert Rose then left Constantinople to travel with different groups serving the needs of soldiers, gypsies, and performers, stability was just a vague memory. She could only think about survival until she was caught by a ruthless mercenary called Jackal Head who took her to a brothel in Konya where she was named Dessert Rose. It is important to note that Desert Rose the Harlot's original name is never revealed in the novel. Beside her 'good shape' the 'patron' named her thus for apparent reasons; namely "to refer to my barrenness, she named me "Desert," and to embellish that name somewhat, she added "Rose," which was fine with me, as I adored roses, explains Desert Rose. (p.178)

The symbolic meaning of 'Desert Rose' is moreover quite significant to the portrayal of Desert Rose's character as investigated by Feminist Love Studies in this research paper. Although she is constantly crushed and 'damaged' by the society from all the abortions, mistreatments and misjudgments through the years of poverty, scarcity and prostitution, Desert Rose manages to manifest the characteristics of the 'Rose'. Though a 'harlot', Desert Rose stands for purity and innocence and retains her humanity through the transformative nature of love.

The brothel became home for Desert Rose, they protected her, up to a certain extent, and gave her everything but her freedom. From "perfumed baths, ointments and scented oils to soften the skin, masks of milk and honey, amber beads to braid her hair, and silk robes all for her use." She could buy these things in the market and she could roam as she pleased only if she was

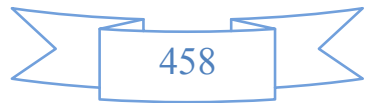


accompanied by a male escort. However, everything comes at a price; Dessert Rose believes the price was not only her body but her soul as well. She had experienced every treatment a 'harlot' can get from tender lovers to men who spat on her face and beat her half to death. She had no hope. She wanted to be God's friend again but she thought her impurity and filth was too much to ever find redemption. She thus thinks about faith: "Faith ... like a hidden rose garden where I once roamed and inhaled its perfumed smells but can no longer enter. I want God to be my friend again. With that longing I am circling that garden, searching for an entrance, hoping to find a gate that will let me in." (p.171)

Although Desert Rose feels that her body is tainted as a prostitute, she still longs for God. She believes that it is in the Love of God that she can find peace for her estranged soul if not her worn out body. She thus explains her longing:

One morning I woke up bursting with a desire to listen to the great Rumi preach. Had I told the patron the truth and asked permission, she would have made fun of me. "Since when do whores go to mosques?" she would have said, laughing so hard her round face would have turned crimson. That's why I lied. (p.170)

As emphasized by the Feminist Love Studies, no one, not even a prostitute, is immune to the positive productive power of love. Traditional philosophy has widely propagated that love, in this case the love for God, is not for those who appear to be unrighteous and unholy. For those like Desert Rose, a prostitute who is seen as 'dirty' by the society and herself, can hardly ever encounter love, or the love of God. On the contrary, Desert Rose encounters 'love', which was implanted by Shams' words, and through 'love' she finds the strength and power to find self-love, self-acceptance, of the good and not-so-good parts of herself, and thereby self-respect and self-transformation.

Yearning for God's love, Desert Rose dresses like a man to visit the mosque which is the only way she can sneak in a mosque to listen to the great Rumi's preach before the Friday prayer. In the mosque, "men of all ages and professions occupied every corner, even the place in the back that would normally be reserved for women." Desert Rose was about to give up and leave when she "noticed a beggar relinquish his seat." "Thanking my lucky stars," however she says, she "wriggled into his space." She listened to Rumi saying, "God created suffering so that joy might appear through its opposite," "Things become manifest through opposites. Whatever happens do not forget, nothing God has created is in vain, whether wrath or forbearance, honesty or guile." (pp.178-179)

Sitting there, Desert Rose feels assured that everything in her life has served a purpose. Behind all hardships" she thinks, is "a larger scheme. [she] couldn't make it out clearly, but could feel it with [her] whole heart." Listening to Rumi in the mosque on that afternoon, Desert Rose gets overwhelmed by the 'power of God's Love', she feels delighted and soothed as if "a cloud of tranquility

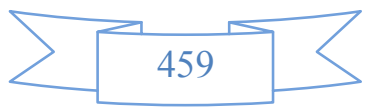


descend(s) over" her.(p.179) This reflects the feminist thought on love as an important creative force, conceiving the energy and the capacity for change.

Upon the discovery of her disguise, however, the angry mob chases her to beat the life out of her by having her 'lynched' or stoned to death. Among the mob is Baybars, the furious and monstrous soldier who is a frequent visitor to the brothel. "I had been through harder things in my life, and yet I doubt if I had ever felt so dejected before," Desert Rose thus describes the brutal discovery:

In a flash Baybars had reached me, so menacingly close I could smell his breath. Grabbing me by the arm, he said between clenched teeth, "What is a harlot doing here? Don't you have any shame?" ... His friends joined him. Tough, scary, confident, disdainful fellows, reeking of anger and vinegar, raining insults on me. Everyone around turned to see what the commotion was about ... but nobody intervened ... I meekly let them push me.... Once we reached the street ... the men grew more belligerent and aggressive. I realized in horror that ... there was nothing to stop them. (pp.197-198)

This is typically ironic from a feminist philosophical approach on love. On one hand, it reveals that these people who have assembled in the mosque to remember and practice their love for God and follow the right path are seething with hatred and anger waiting for the opportunity to vent it," lash the deceiver, lash the whore!" On the other hand, it reflects the hypocrisy of the society and people's attitudes about religion which allows a 'harlot' no such thing as redemption. The so-called custodians of society, like Baybars, are the ones who abhor women becoming prostitutes but at the same time, they cannot allow these women to repent and claim a decent life. This attitude towards Desert Rose based on her profession momentarily inhibits her quest of love: "I should never have gone there," she says, "They're right ... A harlot has no place in a mosque or a church or in any of His houses."'(p.199)

"Don't say that!" says Shams Tabriz, 'the wandering dervish', interrupting Desert Rose's thought. Shams is a man of 'faith' and 'special talents'. His meeting with Desert Rose at this point in her life is very significant as it brings about to her the positive understandings of the nature of love as a powerful means of transformation. After meeting Shams, Desert Rose goes from being a prostitute seen as 'dirty' into being a woman steadfastly working to find God, find more love and leave everything from her old life behind through the transformative nature of love introduced to her by Shams. After all, it is only through the productive positive transformative nature of love that one can transcend such a fate and reach out for self- empowerment and thereby self-transformation: "it is our hearts that make the difference." (p.200)

Noticing Desert Rose's self-hatred after being shoved out of the mosque by Baybars and the mob, Shams bestows on her one of the Forty Rules of Love: "If

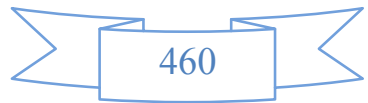


you want to change the way others treat you, you should first change the way you treat yourself. Unless you learn to love yourself, fully and sincerely, there is no way you can be loved." Manipulated by the society, Desert Rose's, "aura has lost its shine" because of all those years she has convinced herself as 'dirty', Shams observes. She has come to doubt her self-worth and believe others'. Shams awakens her soul by inquiring, "How can you blame others for disrespecting you when you think of yourself as unworthy of respect?"(p. 201) Shams, the dervish, further adds that she is 'cleaner than 'fresh spring water'. Desert Rose feels bewildered and stunned; it feels like 'a tasteless joke for her': I stood there unable to say a word as I felt my grip on what was real slip away. I thought about all the men I had slept with.... I had seen nice boys turn into monsters and monsters turn into nice boys... [They] would all say, "You dirty whore.'(p.201)

But Shams interrupts her thoughts and persists on the importance of selfacceptance and self-love by elaborating that "The past is a whirlpool," if one lets it dominate the present moment, it will suck one in. At this moment, Desert Rose starts wondering that maybe "Time is just an illusion" and maybe all one needs is to live at this very moment. "That is all that matters." Shams further explains that visits to temples, mosques, or churches are not truly fruitful if the heart is evil and devoid of love. When Shams has stepped in on behalf of Desert Rose to diffuse the situation with Baybars and the mob, he tells the men, "You go to the mosque but pay more attention to the people around you than to God? If you were the good believers you claim to be, you would not have noticed this woman even if she were naked." (pp.201-202)

Unlike these men, Shams stresses, Desert Rose's "heart is pure and [she] bear(s) God within." Before leaving her, Shams urges Desert Rose to leave the Brothel, leave her past behind and seek self-transformation through love:

Just walk out of that brothel...Fret not where the road will take you. Instead concentrate on the first step. That's the hardest part and that's what you are responsible for. Once you take that step let everything do what it naturally does and the rest will follow. Do not go with the flow. Be the flow."(p.202)

The complete transformation of Desert Rose, however, is noticeably seen after Baybars has almost beaten her to death. According to Feminist Studies of Love it is of great the importance to rethink love as a transformative force that involves social practices aiming at change. (Jónasdóttir 2014, p.12) From this perspective, love can be perceived as a potential force and/or energy that is manifested by transformative and empowering practices. (Toye 2012, p.46) The feminist thinking further describes love as a 'creative expression', a 'vigorous activity' and a means for resistance through the process for transformation (Jaggar 2011, p.25) This view of love is clearly mirrored in the depiction of the character of Desert Rose.

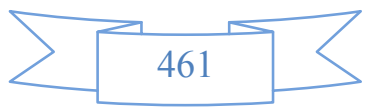


Upon meeting Desert Rose, Shams has planted the seed of love in her. This love is with time watered through her practices and gives her the courage and bravery needed to leave the Brothel and thereby achieve self-transformation. Without the help of Shams, without love that is to say, Desert Rose would have never had the courage to overcome her fears and leave the brothel she has recognized as home for so many years. Love is evidently perceived as the potential force and energy which has resulted in Desert Rose's self- transformation.

After the sandal caused by her visit to the mosque, Desert Rose is never allowed to go out of the brothel even when escorted; "I am grounded forever," she says. But this does not seem to upset her. Desert Rose has not been herself since she has talked with Shams. Love has awakened her soul and left her craving for change. She thus describes her days now at the brothel:

Every morning the face that greets me in the mirror looks paler. I don't comb my hair or pinch my cheeks to redden them anymore. The other girls constantly complain about my bad looks, saying that it keeps the customers away. They may be right... But it doesn't upset me. (p. 316)

One day, however, and to her surprise, Desert Rose is told that a particular client is insisting on seeing her. To her 'horror' it turns out to be Baybars. His unforeseen visit tells much about the hypocrisy and evils of the society; the man who wanted to kill Desert Rose for being a 'harlot' and in the mosque is the same man who now desires her. However, Baybars sees nothing strange about his visit which highlights his hypocritical attitude towards religion. He thus explains his visit to the brothel: "Well, my coming to a brothel is no more bizarre than a harlot going to a mosque." Inspired by the change her soul is harboring, Desert Rose finds for the first time the courage to question Baybars's attitude that day in the mosque, she says, "What is a security guard like you doing here? ... I am sure you would have loved to lynch me that day." Driven by her awakened bravery, Desert Rose goes further and declares that she owes her life to Shams of Tabriz and discloses that "Since that day Shams of Tabriz has come to see me many times."(pp. 216-217)

The journey of self-transformation has been ongoing for some time. Throughout her talks with Shams, Desert Rose slowly but surely comes in close contact with her true self. Desert Rose does not fear Baybars anymore, "I had never told this to anyone else before," she confirms. Desert Rose cannot even understand her act of boldness and as a matter of fact is strikingly stunned, "I had no idea why I was telling Baybars now," she confirms. Shams has been visiting her every week for the past several months. "How he managed to sneak inside without being seen by the others, especially by the patron," Desert Rose has never comprehended, "it was with the aid of black magic she wonders. This, however, has never seemed important as long as she can meet with Shams. (P.217)

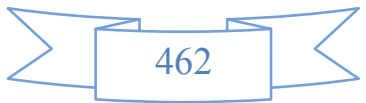


Desert Rose realizes that Shams is "the only person who treated her with 'unconditional compassion'." He has given her the key to self-love and selfacceptance of who she is for real. Shams has instructed Desert Rose to perceive herself not as labeled by the society, a fallen 'dirty' harlot, but rather as a 'clean' and 'whole' soul. Shams has taught Desert Rose "not to be despondent, no matter what." she is by no means confined to the dictates of her past full of poverty and prostitution. She is 'free' to seek and impact change: he always reminds her that:

The past is an interpretation. The future is an illusion. The world does not move through time as if it were a straight line, proceeding from the past to the future. Instead time moves through and within us, in endless spirals. Eternity does not mean infinite time, but simply timelessness. If you want to experience eternal illumination, put the past and the future out of your mind and remain within the present moment ... "You see, the present moment is all there is and all that there ever will be. When you grasp this truth, you'll have nothing to fear anymore. (pp. 201-202)

The words of Shams are of deep significance and consequence. Following the thought of Feminist Love Studies, it is because of the transformative nature of love instilled in her soul by Shams, that Desert Rose is now able to act differently without 'fear'. When Baybars asks her to indulge him with pleasures asking, "What is your specialty? Don't you girls each have a talent?" Desert Rose affirms that she has changed: "I told him I didn't have such talents and whatever gift I had in the past was gone now." Neglecting what she has just said, partly denying it and partly not caring, Baybars grabs her by the hair and has sex with her "in one harsh, abrasive thrust". Although he is clearly 'dissatisfied', he looks at her face with 'pure hatred' and says, "From now on, I want you to be my mistress." For the old Desert Rose that was a common request from her clients, "I knew how to handle these delicate situations, giving the client the false impression that I would love to be his mistress and serve, solely him, but for that to happen he had to spend a lot of money and make the patron happy first."(pp. 317-318)

Desert Rose, however, can no longer keep her silence and go on pretending to be the 'harlot' she now realizes she is not. After being ruthlessly exploited, she feels fearless. She is ready to literally stare death in the face: "I can't be your mistress," she says. "I am going to leave this place very soon." to which Baybars guffaws. Desert Rose now fears no one or anything. She knows that she should not be quarreling with him, but she could not help it. She bluntly reveals the new 'she' and says: "You and I are not that different. We both have done things in the past that we deeply regret." Baybars has no response but to grab her by the hair. He punches her in the face. She says, "It wasn't the first time...I fell on the floor, and then Baybars started to kick me hard in the ribs and legs while hurling insults at me." (pp. 318-319)

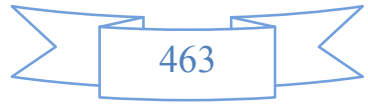


After being beaten by Baybars and looking death in the face, Desert Rose feels that something within her has 'changed irreversibly'. It was as if she has 'no more fear'. It was then and that Desert Rose has had her courage and bravery to reach her complete self-transformation, "I had the strangest experience," she confirms. At the moment and as her body crushes "under the weight of each blow," her 'soul' feels 'light' and 'free'. She thus describes her feeling:

It felt like falling, except falling upward into the bottomless sky. Was I dying? If this was what death was like, it wasn't terrifying at all. My worries diminished. I had tumbled into a place of absolute lightness and purity, a magic zone where nothing could pull me down. (p.321)

Desert Rose now realizes that she can find her freedom within her heart, the 'magic zone' where light and 'purity' resides. She fully apprehends the power of self-respect and self-compassion as her way out of this hard existence of her. Desert Rose thus describes her transformation:

I was living my fear and, to my surprise, it wasn't frightful. Wasn't it because of the fear of being harmed that I had been scared to leave the brothel all this time? If I could manage not to be scared of death, I realized with an expanding heart, I could leave this rat hole. Shams of Tabriz was right. The only filth was the filth inside. I shut my eyes and imagined this other me, pristine and penitent and looking much younger, walking out of the brothel and into a new life. Glowing with youth and confidence, this was what my face would have looked like if only I'd experienced security and love in my life.(pp.320-322)

Glowing with youth and confidence and illuminated by the power of love, Desert Rose is now determined to dedicate what remains of her life to God. As reflected in Feminist Love studies, it is 'love' as a positive productive force that transforms human beings into heroes. Desert Rose concludes:

I was determined to dedicate what remained of my life to God. Whether this would be for a single day or for many more years to come did not matter. Shams of Tabriz had said that faith and love turned human beings into heroes because they removed all the fear and anxiety from their hearts. I was beginning to understand what he meant. (p.337)

\section{Conclusion}

After examining the portrayal of the character of Desert Rose the Harlot in Elif Shafak's The Forty Rules of Love, the researcher reaches the conclusion that love, found in places unexpected and brusquely, is the only path for selftransformation. 
The research paper uses the recent Feminist Love Studies as its framework. This broad field of scholarship has emerged internationally and has been expanding since the early 1990s. Since the beginning of the twenty-first century, the topic of love has been taken seriously as a subject of academic research. Feminist studies has endorsed Love Studies as a new field and has identified with some key features indicating what the feminist academic interest in Love Studies is about. The most relevant feature, however, to the scope of this research paper is the philosophical approach. This approach connects love to creativity and/or perceives it as a productive power of some specific kind. In The Forty Rules of Love, the transformation of the character of Desert Rose the Harlot is examined in the light of Feminist love studies revealing love as the only path to it.

It is revealed that although love is a prominent theme in the novel, it is not just about love itself. It is rather about the major transformations that take place because of love. The most intriguing story of all in the novel is that of Desert Rose the Harlot for she changes from a prostitute because of her love for God. Through her relationship with Shams of Tabriz, Desert Rose discloses the defects of the society, which belittles and disgusts her as a 'harlot', and the beauty of the human heart, which can transcend all obstacles through love and its innate purity. The words of love she receives from Shams inspires Desert Rose to find her means to self-respect and self-transformation.

Desert Rose is motivated to abandon the apparent doubtful safety and security of her life as a wrecked harlot in the brothel for the uncertainty and ecstasy of love. Although, this cannot present Desert Rose the promise of lasting undisturbed happiness and security. It can offer her a taste of divine love and deep harmony that arises when the false self constructed to only meet the dictates of the society is shed and the true self emerges. This self-transformation creates nothing but revenue to living an authentic life.

Destiny doesn't mean that your life has

been strictly predetermined. Therefore, to live everything to the fate and to not actively contribute to the music of the universe is a sign of sheer ignorance. The music of the universe is all pervading and it is composed on 40different levels. Your destiny is the level where you play your tune.

You might not change your instrument but how well to play is entirely in your hands. (Shafak 2009, p.229) 


\section{References}

Adriana, G.A. \& Jonasdottir, A. (2014). The Contradictions of Love. New York: Routledge.

Barriteau, E. (2012). Love and Power. Cave Hill, Barbados: University of the West Indies Press.

Davis, D. R. (2002). "Love Is the Ability of Not Knowing". Hypatia 17 (2): 14561.

Ferguson, Ann. 1991.Sexual democracy. Boulder, Colo.: Westview Press.

Eaten, P.W. (2017) "What the World Needs Now: Elif Shafak's "The Forty Rules of

Love." profpeaton.com/2017/07/02/what-theworld-needs-now-elif-shafaks-theforty-rules-of-love/.

Jaggar, A. (2011). Love and knowledge. In Gender/Body/Knowledge. New Brunswick, N.J.: Rutgers University Press.

Jónasdóttir, A. (1994). Why Women are Oppressed. Philadelphia: Temple University Press.

(2014). A Renewed Field of Feminist Knowledge Interests. In Love: A Question for Feminism in the Twenty-First Century, ed. Anna G. Jónasdóttir and Ann Ferguson. London: Routledge

Mishra, P. (2016) Age of Anger: a History of the Present. Penguin Books, 2018. Sidhwa, Bapsi. Ice-Candy-Man. Daunt Books, 2016.

Shafak, Elif. (2009) The Forty Rules of Love. Penguin Random House.

(2018) "Why the Novel Matters in the Age of Anger." New

Statesman, 3 Oct. 2018, www.newstatesman.com/culture/books/2018/10/whynovel-matters-age-anger.

. (2009) "Under the Spell of Divine and Human Love: Taking a Long Journey into Yourself." Interviewed by Nezli Demiroz, 24 Mar. 2009, www.elifsafak.us/en/roportajlar.asp?islem=roportaj\&id=17

Toye, M.E. (2012). Towards a Poethics of Love. Feminist Theory 11 (1): 39-55.

(2014) Forthcoming. Love as affective energy. In Feminism and the Power of Love, ed. Adriana Garcia Andrade, Lena Gunnarsson, and Anna Jonasdottir. Routledge. 
يعد الحب جزء أساسى من التجربة الإنسانية الفريدة ، ولقد كان للحب دائمًا تأثثر كبير وأهمية في الأدب العالمي. ويعد الحب من الموضوعات الأكثر تتاولا في الأدب بما يمثله من عمق وتتوع واثارة وتتثويق. وقد حاول الكتاب والنقاد على مر العصور دراسة موضوع الحب فى كتابتهم الادبية والنقدية وذلك لكثف وبحث أنواع الحب المختلفة فى النفس الانسانية والنتائج المترتبة على الحب في ما تشهده النفس من تغيرات. وتعد الكاتبة الروائية التركية البارزة أليف شفق من أهم الكتاب الذين انشغلوا بالحب في كتاباتهم فى الوقت المعاصر . - م

ويمثل أهتمام أليف شفق بموضوع الحب أهمية كبيرة في هذا البحث. ففي روايتها " قواعد الحب الأربعون " (9 . ץ) ، تتعرض شفق لموضوع الحب من خلال الثخصيات المتعددة فى الرواية وذلك برسم أبعاده الإلهية والإنسانية، وتقدم شفق الحب على أنه جوهر الحياة وهدفها. وبعيدا عن الانتقادات الراديكالية للدور الذي لعبه الحب في الحفاظ على الأنماط والقوالب الأبوية فى المجتمع ووصولا إلى التفكير الأساسي حول الحب كقوة إيجابية ومنتجة ، فقد لعب الحب أيضًا دورًا مهمًا في النظرية الأدبية والنقد النسوي طوال تاريخه. هذا ويتأخذ هذا البحث من دراسات الحب النسوية الحديثة إطار لدراسة الحب ويتمكن البحث من الكثف عن القوة الايجابية والموثرة للحب كالمسار الوحيد لاحداث التحول الذاتي وذلك من خلال تحليل شخصية زهرة الصحراء الزانية في رواية " قواعد الحب الأربعون " للكانبة أليف شفق.

الكلمات المفتاحية: الحب ، التحول الذاتي ، النظرية النسوية ، دراسات الحب النسوي ، التعبير عن 